\title{
Publisher Correction: Influences of organic carbon speciation on hyporheic corridor biogeochemistry and microbial ecology
}

\author{
James C. Stegen (10 1, Tim Johnson', James K. Fredrickson', Michael J. Wilkins (1) 2,3, Allan E. Konopka1, \\ William C. Nelson (1) 1, Evan V. Arntzen', William B. Chrisler', Rosalie K. Chu (1) 1, Sarah J. Fansler (1) 1, \\ Emily B. Graham (10 1, David W. Kennedy (10 ${ }^{1}$, Charles T. Resch', Malak Tfaily (i) ${ }^{1} \&$ John Zachara ${ }^{1}$
}

Correction to: Nature Communications https://doi.org/10.1038/s41467-018-02922-9, published online 08 February 2018

The original version of this Article contained an error in Fig. 6e, in which the text in the legend was omitted. This has been corrected in both the PDF and HTML versions of the article.

Published online: 07 March 2018

\begin{abstract}
(c) (i) Open Access This article is licensed under a Creative Commons Attribution 4.0 International License, which permits use, sharing, adaptation, distribution and (c) reproduction in any medium or format, as long as you give appropriate credit to the original author(s) and the source, provide a link to the Creative Commons license, and indicate if changes were made. The images or other third party material in this article are included in the article's Creative Commons license, unless indicated otherwise in a credit line to the material. If material is not included in the article's Creative Commons license and your intended use is not permitted by statutory regulation or exceeds the permitted use, you will need to obtain permission directly from the copyright holder. To view a copy of this license, visit http://creativecommons.org/licenses/by/4.0/.
\end{abstract}

(c) The Author(s) 2018

\footnotetext{
${ }^{1}$ Pacific Northwest National Laboratory, Richland, WA 99352, USA. ${ }^{2}$ Department of Microbiology, The Ohio State University, Columbus, OH 43210, USA ${ }^{3}$ School of Earth Sciences, The Ohio State University, Columbus, OH 43210, USA. Correspondence and requests for materials should be addressed to J.C.S. (email: James.Stegen@pnnl.gov)
} 